\title{
ARTICLES
}

Submitted 04.29.2016. Approved 10.04.2016

Evaluated by double blind review process. Scientific Editor: Antonio Lopo Martinez

DOI: http://dx.doi.org/10.1590/So034-759020170403

\section{REVISITING THE SIZE EFFECT IN THE BOVESPA}

\author{
Análise do efeito tamanho na Bovespa \\ Análisis del efecto tamaño en el Bovespa
}

\begin{abstract}
The size effect has been analyzed in numerous stock markets using different approaches. However, there are few studies focused on its practical applicability. In this context, the aim of this study is two-fold. First, we examine price and volatility linkages among large, medium, and small firms employing a multivariate VAR-BEKK model. Second, we provide the out-of-sample performance of optimal portfolios constructed on the basis of time-varying return and volatility forecasts from this specification approach. Our overall results show that optimal portfolios are primarily composed of medium and small firms. Moreover, our findings reveal that using this technique, it is possible to reduce risk and outperform the naïve rule, which is usually employed by foreign investors interested in the Brazilian stock market. These findings are relevant not only for academics but also for practitioners because it is important an in-depth knowledge of stock market patterns in order to develop correct trading strategies.
\end{abstract}

KEYWORDS | Multivariate GARCH, optimal strategies, size effect, statistical and economic significance, Bovespa.

\section{RESUMO}

O efeito tamanho vem sendo analisado em diversos mercados de ações, utilizando-se diferentes perspectivas. No entanto, existem poucos estudos focados em sua aplicação prática. Nesse contexto, o objetivo do presente estudo é duplo. Primeiramente, vamos examinar as relações entre os preços $e$ as volatilidades das empresas grandes, médias e pequenas, usando um modelo VAR-BEKK multivariado. Em segundo lugar, analisamos o desempenho das carteiras ótimas obtidas a partir das previsões de rentabilidade e volatilidade variáveis no tempo, derivadas do modelo multivariado. Os resultados globais mostram que as carteiras ótimas são compostas principalmente por empresas de tamanho médio e pequeno. Além disso, nossos resultados revelam que, com a utilização dessa técnica, é possível reduzir o risco e melhorar a carteira "naïve", que é normalmente utilizada pelos investidores estrangeiros interessados no mercado brasileiro. Esses resultados são relevantes não só para os acadêmicos, mas também para os profissionais, já que é importante conhecer em profundidade o comportamento dos mercados acionários para desenvolver uma estratégia acionária correta.

MARIA DEL MAR MIRALLES-QUIROS

marmiralles@unex.es

Professor at Universidad de

Extremadura, Facultad de Ciencias

Económicas y Empresariales -

Badajoz, Spain

JOSE LUIS MIRALLES-QUIROS

miralles@unex.es

Professor at Universidad de

Extremadura, Facultad de Ciencias

Económicas y Empresariales -

Badajoz, Spain

\section{LUIS MIGUEL GONÇALVES}

miguel.mvgoncalves@gmail.com Ph. D. Student at Universidad de Extremadura, Facultad de Ciencias Económicas y Empresariales Badajoz, Spain
PALAVRAS-CHAVE / GARCH multivariado, estratégias ótimas, efeito do tamanho, significância estatística, econômica, Bovespa.

\section{RESUMEN}

El efecto tamaño ha sido analizado en diversos mercados de acciones utilizando diferentes perspectivas. Sin embargo, existen pocos estudios que se centren en su aplicación práctica. En este contexto, el objetivo de este estudio es doble. En primer lugar, vamos a examinar las conexiones entre los precios y las volatilidades de las empresas grandes, medianas y pequeñas empleando un modelo VAR-BEKK multivariante. En segundo lugar, analizamos la performance de las carteras óptimas obtenidas a partir de las predicciones de rentabilidad y volatilidad variables en el tiempo derivadas del modelo multivariante. Los resultados globales muestran que las carteras óptimas están compuestas principalmente por empresas de medio y pequeño tamaño. Además, nuestros resultados revelan que con la utilización de esta técnica es posible reducir el riesgo y mejorar la cartera naïve, que normalmente es utilizada por los inversores extranjeros que están interesados en el mercado brasileño. Estos resultados son relevantes no sólo para los académicos sino también para los profesionales porque es importante conocer en profundidad el comportamiento de los mercados bursátiles para desarrollar una correcta estrategia bursátil.

PALABRAS CLAVE / GARCH multivariante, estrategias óptimas, efecto tamaño, significatividad estadística, económica, Bovespa. 


\section{INTRODUCTION}

As one of the several market anomalies, the size effect has been the subject of numerous studies in several markets. Small company shares usually have a higher performance than that of large companies for the same period. This concept was developed following tests in several countries that found some additional information. First, as far as the returns of series of shares are concerned, when analyzing a long period, we have observed that in some sub-periods, small company shares may have a lower performance than the shares of large companies. However, when analyzing a long period as a whole, small company shares have a higher performance. Second, even when returns are risk-adjusted, the small caps returns exceed the theoretical value.

Specifically, the size effect was first evidenced by the work of Ibbotson and Sinquefield (1976). Later, Banz (1981) studied the phenomenon in the market where the shares of companies with low capitalization have a different return than expected when calculated by the traditional theoretical models. Bowers and Dimson (1988) define the anomalies as existing phenomena in some market segments that cannot be explained by traditional risk models. This study has proved to be important, as it observed better returns on smaller size securities, which allows for extraordinary gains by investors. More recent studies, such as those by Fouse (1989), Berk (1997), Carhart (1997), Ewing and Malik (2005) and Fama and French (1995, 2008, 2012), confirm the existence of the size effect in the U.S. market.

Numerous studies in several markets and over several periods suggest that the occurrence of such an effect is a global phenomenon. The difference lies in the justification of its causes and in the implications of this phenomenon. This can be verified in the work performed by several researchers in various markets, from the Australian market studied by Brown et al. (1983) to the Spanish market studied by Miralles-Marcelo et al. (2011).

The study of the Brazilian market reflects the great interest of international investors that look for extraordinary gains in lessefficient emerging markets but with the confidence needed to secure and protect their investments, which includes Brazil as the largest market in South America where regulation and institutions work according to international standards. The Brazilian capital market has shown two significant signs that it began a new phase in 2003: 1) economic stability and the improvement of regulation; and 2) the significant increase in the degree of confidence of all market players, evidenced in an expansion of companies' capital and in the increase in trading volumes and debt instruments. On the other hand, the interest of investors, both institutional and individual, as well as foreign and domestic, has shown that the Brazilian market is able to meet the creation needs of longterm assets.

The analysis of the market informational efficiency is important to map out investment strategies. Fama (1991) pointed out that the empirical work on the informational content of financial asset prices led to the emergence of passive strategies of purchase and maintenance of diversified portfolios in response to the difficulty of beating the market based solely on the analysis of public information.

In this context, we have sought to obtain the statistical and economic significance for the Brazilian market regarding the size effect. We have identified the occurrence of the phenomenon in both an in-sample and out-of-sample period, proving that adopting a strategy of optimal portfolios performs better than a naive strategy.

The remainder of the paper is organized as follows. In the next section, we review the previous empirical evidence. Thereafter, we describe the methodology. Next, we present the database on which the study is based and we describe the results. Finally, we present the main findings.

\section{PREVIOUS EMPIRICAL EVIDENCE}

Evidence on the size effect documented by lbbotson and Sinquefield (1976) led to further interest from other researchers in its detection and understanding. Studies such as the one carried out by Banz (1981) prove that using traditional theoretical models results in unexpected returns for companies with low capitalization. The study by Reinganum (1981), based on the research of Basu (1977), covered the period between 1963 and 1977. It demonstrated that portfolios consisting of small cap assets have a higher average return than portfolios consisting of large cap assets.

The size effect, as documented by Banz (1981), is based in the empirical evidence that stocks of small companies have higher average returns than the stocks of large companies. That evidence is an anomaly because there are no theoretical reasons for a proxy of company size to have the statistical capability to explain return differences in a cross-section, after controlling for risk (Chan et al., 1985).

Due to this evidence, some studies have sought to clarify, in theoretical terms, the size effect. In the U.S. market, Roll (1981) studied the behavior of stock returns throughout the year, adding that low cap securities have abnormally high returns in the last trading days of December. Another study from Keim (1983) documented that 50 percent of the year's size effect is 
concentrated in the first five trading days of January. Roll (1983), Blume and Stambaugh (1983) found that portfolios built and reorganized on a daily or monthly basis have a higher presence of the size effect. When Keim and Stambaugh (1984) studied the effect based on daily returns, they found not only that this effect can be observed on a daily basis but also that it is more pronounced on Fridays. Fouse (1989) concluded that this effect was due to the low liquidity of small company shares. Berk (1997) argued that the size effect is a consequence of the size proxy used. More recently, Ewing and Malik (2005) investigated the existence of asymmetry in the predictability of small and large companies' volatilities. In addition, the empirical evidence on the size effect in the U.S. market subsequent to the abovementioned has contributed to a more complete characterization of the phenomenon.

Studies have documented the existence of such an effect in several international stock markets: Brown et al. (1983) studied the Australian market in the period 1958-1981; Reinganum and Shapiro (1987) studied the London market during the period 1956-1980; Berges et al. (1984) studied the Canadian market for the period 1951 to 1980; and Nakamura and Terada (1984) studied the Japanese market from 1966 to 1983 . The existence of the size effect was proven in all countries. However, it is not possible to carry out a more detailed comparison because the analysis period differs from market to market and the methodologies used vary.

More recently, the study by Van Dijk (2011) reviews 30 years of research on the size effect on stock returns. Miralles-Marcelo et al. (2011) examines the transmission of information in the Spanish market and Amel-Zadeh (2011) confirms the existence of a size anomaly in the German market, contrary to recent evidence of a reversal of the size anomaly. Cakici et al. (2013), using sharelevel data between January 1990 and December 2011, find strong evidence for the value effect in all emerging markets and for the momentum effect in all eastern European markets. Israel and Moskowitz (2013) analyze the role of shorting, company size and time on the profitability of size, value, and momentum strategies. Zakamulin (2013) provides evidence that the small share premium is predictable both in-sample and out-of-sample using offset macro-economic variables.

In the Brazilian market, several studies confirm the existence of the size effect, as summarized in Table 1 , which indicates the period under study as well as the analysis methodology used. Eid and Romaro (2002), after applying empirical tests on share portfolios on the BOVESPA, in the period from 1995 to 1998 , found evidence that the average returns of portfolios comprised of small cap companies is lower than that of high capitalization companies. Matsumoto and Lima (2004) found evidence, according to previous investigations, of the reversal of returns between large and small companies' shares, in addition to the positive trend of achieving higher returns with larger size assets, especially in troubled periods of the economy. Lima et al. (2005) conclude the existence of the effect from the perspective of the Capital Asset Pricing Model (CAPM), and its absence when analyzed from the perspective of the market model.

\section{Table 1. Empirical evidence for the Brazilian market}

Found evidence of the occurrence of the anomaly

\begin{tabular}{l|l|l}
\hline Author & Analysis period & Methods and tests used \\
\hline Eid and Romaro (2002) & 1995 to 1998 & $\begin{array}{l}\text { Linear regression, average, variance, skewness and kurtosis, method of least squares, } \\
\text { Durbin-Watson, Breusch-Godfrey, Q Lyung-Box, Goldfeld and ARCH-LM tests }\end{array}$ \\
\hline Matsumoto and Lima (2004) & 1996 to 2003 & Linear regression \\
\hline Lima et al. (2005) & 1995 to 2003 & Linear regression, CAPM, market model \\
\hline \multicolumn{2}{|c}{ Found no evidence of the occurrence of the anomaly } \\
\hline Author & Analysis period & Methods and tests used \\
\hline Lucena and Figueiredo (2004) & 1994 to 2003 & $\begin{array}{l}\text { Linear regression, model of three factors, autoregressive models of Box and Jenkins, } \\
\text { and Grinblatt and Moskowitz model }\end{array}$ \\
\hline Antunes et al. (2006) & 1998 to 2004 & Simple arithmetic average, CAPM and Jensen's alpha indicator \\
\hline Flister et al. (2011) & 1995 to 2008 & Linear regression and CAPM \\
\hline Saturnino et al. (2012) & 1995 to 2010 & Linear regression and CAPM \\
\hline Machado and Machado (2014) & 1995 to 2008 & Linear regression, model of two factors, model of three factors and CAPM \\
\hline
\end{tabular}


Conversely, several studies found no evidence of such an effect, as exemplified by the studies of Lucena and Figueiredo (2004), based on the multi-factor model of Fama and French, and on the regression presented by Grinblatt and Moskowitz (2002). Flister et al. (2011), Saturnino et al. (2012) and Machado and Machado (2014) also found no evidence of such an effect.

The aforementioned Brazilian market studies all employ a simple analysis methodology using a linear regression. Furthermore, these studies only analyze up until 2008 , without taking into account the years following the current financial crisis. This study, however, adopts a more complex methodology, utilizing VAR-BEKK modeling and optimal investment strategies, as described in Methodology section. Furthermore, this study analyzes a morerecent and broader time period of 20 years from 1994 until 2014.

\section{METHODOLOGY}

This section is divided into three main sub-sections. First, we present the multivariate model used to estimate the returns and conditional volatilities of three portfolio sizes: large, medium, and small. Second, we describe the methodology for the construction of optimal investment strategies based on information obtained from the multivariate model. Finally, we describe the criterion used to evaluate the performance of alternative strategies.

\section{Multivariate VAR-BEKK model}

The econometric specification used in this study consists of two components. First, to model the returns, we used a vector autoregression with $\mathrm{k}$ lags, which enables autocorrelations and cross-correlations in the returns.

$$
\begin{gathered}
\mathrm{R}_{\mathrm{i}, \mathrm{t}}=\mathrm{c}_{\mathrm{i}}+\sum_{\mathrm{k}=1}^{\mathrm{K}} \sum_{\substack{\mathrm{i}=1 \\
\mathrm{j}=1}}^{3} \alpha_{\mathrm{ij}} \mathrm{R}_{\mathrm{i}, \mathrm{t}-\mathrm{k}}+\varepsilon_{\mathrm{i}, \mathrm{t}} \\
\varepsilon_{\mathrm{it}} \mid \Omega_{\mathrm{t}-1} \approx \mathrm{N}\left(0, \mathrm{H}_{\mathrm{t}}\right)
\end{gathered}
$$

Second, to model the conditional covariance matrix, we used a multivariate GARCH model. One of the most commonly used models is the BEKK model by Baba et al. (1991). The covariance matrix of the BEKK model is calculated through the expression

$$
\mathrm{H}_{\mathrm{t}}=\mathrm{C}^{\prime} \mathrm{C}+\mathrm{A}^{\prime} \varepsilon_{\mathrm{t}-1} \varepsilon_{\mathrm{t}-1}^{\prime} \mathrm{A}+\mathrm{B}^{\prime} \mathrm{H}_{\mathrm{t}-1} \mathrm{~B}
$$

where, in this case, $C$ is a lower triangular matrix $(3 \times$ 3) with six parameters to be estimated, and $A$ and $B$ are size matrices $(3 \times 3)$, where the first captures the effects of shocks in volatility and the second the effects of conditional variance, delayed by the measurement of the diagonal of both the effects of said shocks and variances, respectively. Using a tri-variant model, the estimated total number of elements in our case is 24 .

$$
\begin{aligned}
H_{t}= & \left(\begin{array}{lll}
c_{11} & \\
c_{21} & c_{22} & \\
c_{31} & c_{23} & c_{33}
\end{array}\right)\left(\begin{array}{lll}
c_{11} & c_{21} & c_{31} \\
& c_{22} & c_{23} \\
a_{21} & a_{22} & a_{23} \\
a_{31} & a_{32} & a_{33}
\end{array}\right) \varepsilon_{t} \varepsilon^{\prime}\left(\begin{array}{lll}
a_{11} & a_{12} & a_{13} \\
a_{12} & a_{22} & a_{32} \\
a_{13} & a_{23} & a_{33}
\end{array}\right)+ \\
& +\left(\begin{array}{lll}
b_{11} & b_{12} & b_{13} \\
b_{21} & b_{22} & b_{23} \\
b_{31} & b_{32} & b_{33}
\end{array}\right) H_{t-1}\left(\begin{array}{lll}
b_{11} & b_{21} & b_{31} \\
b_{12} & b_{22} & b_{32} \\
b_{13} & b_{23} & b_{33}
\end{array}\right)
\end{aligned}
$$


where:

$$
\varepsilon_{\mathrm{t}} \varepsilon_{\mathrm{t}}^{\prime}=\left(\begin{array}{ccc}
\varepsilon_{1, \mathrm{t}-1}^{2} & \varepsilon_{1, \mathrm{t}-1} \varepsilon_{2, \mathrm{t}-1} & \varepsilon_{1, \mathrm{t}-1} \varepsilon_{3, \mathrm{t}-1} \\
\varepsilon_{2, \mathrm{t}-1} \varepsilon_{1, \mathrm{t}-1} & \varepsilon_{2, \mathrm{t}-1}^{2} & \varepsilon_{2, \mathrm{t}-1} \varepsilon_{3, \mathrm{t}-1} \\
\varepsilon_{3, \mathrm{t}-1} \varepsilon_{1, \mathrm{t}-1} & \varepsilon_{3, \mathrm{t}-1} \varepsilon_{2, \mathrm{t}-1} & \varepsilon_{3, \mathrm{t}-1}^{2}
\end{array}\right) \quad \mathrm{H}_{\mathrm{t}}=\left(\begin{array}{lll}
\mathrm{h}_{11, \mathrm{t}} & \mathrm{h}_{12, \mathrm{t}} & \mathrm{h}_{13, \mathrm{t}} \\
\mathrm{h}_{21, \mathrm{t}} & \mathrm{h}_{22, \mathrm{t}} & \mathrm{h}_{23, \mathrm{t}} \\
\mathrm{h}_{31, \mathrm{t}} & \mathrm{h}_{32, \mathrm{t}} & \mathrm{h}_{33, \mathrm{t}}
\end{array}\right)
$$

The conditional variances can be expressed through the development of matrices such as:

$$
\begin{aligned}
\mathrm{h}_{11, \mathrm{t}}= & \mathrm{c}_{11}^{2}+\mathrm{a}_{11}^{2} \varepsilon_{1, \mathrm{t}-1}^{2}+\mathrm{a}_{21}^{2} \varepsilon_{2, \mathrm{t}-1}^{2}+\mathrm{a}_{31}^{2} \varepsilon_{3, \mathrm{t}-1}^{2}+2 \mathrm{a}_{11} \mathrm{a}_{21} \varepsilon_{1, \mathrm{t}-1} \varepsilon_{2, \mathrm{t}-1}+2 \mathrm{a}_{11} \mathrm{a}_{31} \varepsilon_{1, \mathrm{t}-1} \varepsilon_{3, \mathrm{t}-1}+2 \mathrm{a}_{31} \mathrm{a}_{21} \varepsilon_{2, \mathrm{t}-1} \varepsilon_{3, \mathrm{t}-1}+ \\
& +\mathrm{b}_{11}^{2} \mathrm{~h}_{1, \mathrm{t}-1}+\mathrm{b}_{21}^{2} \mathrm{~h}_{2, \mathrm{t}-\mathrm{1}}+\mathrm{b}_{31}^{2} \mathrm{~h}_{3, \mathrm{t}-1}+2 \mathrm{~b}_{11} \mathrm{~b}_{21} \mathrm{~h}_{12, \mathrm{t}-1}+2 \mathrm{~b}_{11} \mathrm{~b}_{31} \mathrm{~h}_{13, \mathrm{t}-1}+2 \mathrm{~b}_{31} \mathrm{~b}_{21} \mathrm{~h}_{23, \mathrm{t}-1}
\end{aligned}
$$

$$
\begin{aligned}
\mathrm{h}_{22, \mathrm{t}}= & \mathrm{c}_{21}^{2}+\mathrm{c}_{22}^{2}+\mathrm{a}_{12}^{2} \varepsilon_{1, \mathrm{t}-1}^{2}+\mathrm{a}_{22}^{2} \varepsilon_{2, \mathrm{t}-1}^{2}+\mathrm{a}_{32}^{2} \varepsilon_{3, \mathrm{t}-1}^{2}+2 \mathrm{a}_{22} \mathrm{a}_{12} \varepsilon_{1, \mathrm{t}-1} \varepsilon_{2, \mathrm{t}-1}+2 \mathrm{a}_{32} \mathrm{a}_{12} \varepsilon_{1, \mathrm{t}-1} \varepsilon_{3, \mathrm{t}-1}+2 \mathrm{a}_{32} \mathrm{a}_{22} \varepsilon_{2, \mathrm{t}-1} \varepsilon_{3, \mathrm{t}-1}+ \\
& +\mathrm{b}_{12}^{2} \mathrm{~h}_{1, \mathrm{t}-1}+\mathrm{b}_{22}^{2} \mathrm{~h}_{2, \mathrm{t}-1}+\mathrm{b}_{32}^{2} \mathrm{~h}_{3, \mathrm{t}-1}+2 \mathrm{~b}_{22} \mathrm{~b}_{12} \mathrm{~h}_{12, \mathrm{t}-1}+2 \mathrm{~b}_{32} \mathrm{~b}_{12} \mathrm{~h}_{13, \mathrm{t}-1}+2 \mathrm{~b}_{32} \mathrm{~b}_{22} \mathrm{~h}_{23, \mathrm{t}-1}
\end{aligned}
$$

$$
\begin{aligned}
\mathrm{h}_{33, \mathrm{t}}= & \mathrm{c}_{31}^{2}+\mathrm{c}_{32}^{2}+\mathrm{c}_{33}^{2}+\mathrm{a}_{13}^{2} \varepsilon_{1, \mathrm{t}-1}^{2}+\mathrm{a}_{23}^{2} \varepsilon_{2, \mathrm{t}-1}^{2}+\mathrm{a}_{33}^{2} \varepsilon_{3, \mathrm{t}-1}^{2}+2 \mathrm{a}_{23} \mathrm{a}_{13} \varepsilon_{1, \mathrm{t}-1} \varepsilon_{2, \mathrm{t}-1}+2 \mathrm{a}_{33} \mathrm{a}_{13} \varepsilon_{1, \mathrm{t}-1} \varepsilon_{3, \mathrm{t}-1}+2 \mathrm{a}_{33} \mathrm{a}_{23} \varepsilon_{2, \mathrm{t}-1} \varepsilon_{3, \mathrm{t}-1}+ \\
& +\mathrm{b}_{13}^{2} \mathrm{~h}_{1, \mathrm{t}-1}+\mathrm{b}_{23}^{2} \mathrm{~h}_{2, \mathrm{t}-1}+\mathrm{b}_{33}^{2} \mathrm{~h}_{3, \mathrm{t}-1}+2 \mathrm{~b}_{23} \mathrm{~b}_{13} \mathrm{~h}_{12, \mathrm{t}-1}+2 \mathrm{~b}_{33} \mathrm{~b}_{13} \mathrm{~h}_{13, \mathrm{t}-1}+2 \mathrm{~b}_{33} \mathrm{~b}_{23} \mathrm{~h}_{23, \mathrm{t}-1}
\end{aligned}
$$

However, more recent studies have documented the importance of considering the asymmetric effects of news on volatility for a better specification of the conditional variance-covariance matrix and the economic implications in terms of asset allocation (Kroner \& Ng, 1998). Following the comprehensive approach of Glosten et al. (1993) proposed by Kroner and Ng (1998), and also used by Karmakar (2010), the model is defined as

$$
H_{t}=C^{\prime} C+A^{\prime} \varepsilon_{t-1} \varepsilon_{t-1}^{\prime} A+B^{\prime} H_{t-1} B+\eta^{\prime} I_{\left(\varepsilon_{t-1}<0\right)} \odot \varepsilon_{t-1} \varepsilon_{t-1}^{\prime} \odot \eta I_{\left(\varepsilon_{t-1}<0\right)}
$$

where $I_{\left(\varepsilon_{t-1}<0\right)}$ is a vector $3 \times 1$ whose elements take the value 1 if the corresponding innovation in the vector $\varepsilon_{t}$ is negative, and $\odot$ is the Hadamard product (element by element) that captures the different volatility responses to negative shocks (bad news) or positive shocks (good news).

The model is estimated by maximizing the likelihood function and assuming normally distributed errors:

$$
\mathrm{L}(\theta)=-\mathrm{T} \ln (2 \pi)-\frac{1}{2} \sum_{\mathrm{t}=1}^{\mathrm{T}}\left(\ln \left|\mathrm{H}_{\mathrm{t}}\right|+\varepsilon_{\mathrm{t}}^{\prime} \mathrm{H}_{\mathrm{t}}^{-1} \varepsilon_{\mathrm{t}}\right)
$$

where $T$ is the number of observations and $\theta$ represents the vector of parameters to be estimated.

Hafner (2008) points out that the BEKK model, which is nested in the VECH model, has been introduced mainly to overcome some practical disadvantages of the VECH model. The same study makes reference to other multivariate GARCH models, such as the CCC and the DCC models. However, Hafner (2008) indicates that these models are not nested in the VECH model and, due to their nonlinear character, create difficulty in deriving aggregation results. Therefore, the researchers primarily use the BEKK model for the 
portfolio hedgings and performances (see Karmakar, 2010, and Miralles-Quiros and Miralles-Quiros, 2017, among others), while the DCC models focus on the time-varying correlations among different markets (see Silvennoinen and Teräsvirta, 2009; Ahmad et al., 2013; and Zhang and Li, 2014).

\section{Optimal portfolios}

Multivariate VAR-BEKK estimates can be applied to various financial purposes. We focus on tactical asset allocation by building portfolios with risk minimization for investors.
According to the classical theory of optimal selection of portfolios by Markowitz (1952), the management of the average variance will allocate resources in the three groups of firms to minimize the variance of the portfolio, subject to the fact that the expected return of the portfolio has to respect a specific target $R^{*}$. It should be noted that volatile periods are usually associated with declines in market values. In these cases, investors accept a higher risk to gain positive returns. For this reason, we have included a condition of expected non-negative return in our optimization. In doing so, portfolio managers seek to find the optimal portfolio weight $w_{t}$ that solves the optimization problem:

$$
\begin{array}{cc}
\min _{w_{t}} & w_{t}^{\prime} H_{t+1 \mid t} w_{t} \\
\text { s.t. } & w_{t}^{\prime} E\left\{R_{t+1}\right\} \geq R^{*} \\
& w_{t}^{\prime} \\
& w_{t} \geq 0
\end{array}
$$

where 1 is a vector of 1 and the non-negative condition $w_{t} \geq 0$ means that the portfolio manager is prohibited from making short sales. It should be noted that these constraints would not be valid if the hedge fund managers were the market players in this context. For this reason, we also consider a version without these constraints, where the optimal solution $\mathrm{w}_{t}$ can contain negative weights, indicating short positions.

\section{Performance evaluation}

We consider the Sharpe ratio for an out-of-sample period as a measure of optimal strategy performance. It is defined as the average of the excess returns sample out-of-sample over the risk-free asset, divided by the sample standard deviation:

$$
\mathrm{SR}_{\mathrm{p}}=\frac{\mu_{\mathrm{p}}}{\sigma_{\mathrm{p}}}
$$

We have also calculated the Sharpe ratio for our benchmark strategy - the naive strategy - which consists of investing the same amount in each of the assets that comprise the portfolio. This easy implementation strategy does not depend on asset return estimates or on optimization techniques. Furthermore, it is still widely used as a simple rule of wealth allocation among assets, despite the development of more sophisticated models and the improvement of estimation methods of the models' parameters. There is also empirical evidence that equally weighted naive portfolios achieve higher performance than that obtained through optimization processes (see, for example, DeMiguel et al., 2009).

To assess the statistical significance of the differences between the performance of the reference strategy (SR Naive) and the optimal strategy, we used a bootstrap inference method. More specifically, using the null hypothesis of $\mathrm{H}_{0}:\left\{\mathrm{SR}_{\mathrm{p}}-\mathrm{SR}_{\text {Naive }}=0\right\}$, we calculate a $\mathrm{p}$-value on one side, following the methodology proposed by Ledoit and Wolf (2008). 


\section{DATABASE}

The initial sample used in this study consists of the shares listed on the São Paulo Stock Exchange provided by the Thomson Financial Datastream database, corresponding to a total of 365 businesses representing 38 segments of the economy during a 20 -year period from 1994 to 2014. With that sample, we built three portfolios of large, medium, and small size based on a weekly frequency.

\section{Table 2. Descriptive statistics}

\begin{tabular}{l|c|c|c}
\hline & Large & Medium & Small \\
\hline Average & 0.0002 & 0.0007 & 0.0024 \\
\hline Standard deviation & 0.0327 & 0.0212 & 0.0256 \\
\hline Skewness & -1.6935 & -1.3052 & 1.4956 \\
\hline Kurtosis & 11.9434 & 19.0896 & 16.3579 \\
\hline Jarque-Bera & 3974.517 & 11546.39 & 8143.228 \\
\hline Probability & $(0.0000)$ & $(0.0000)$ & $(0.0000)$ \\
\hline
\end{tabular}

Table 2 shows the descriptive statistics of the three portfolios: large, medium, and small. We found that the average profitability of small businesses is higher, which is a first indicator of the existence of the size effect. Regarding the analysis of the standard deviation, we observe increased volatility in large firms, so investment in these assets will be of less interest. With respect to other descriptive statistics, the values of skewness and kurtosis show an asymmetry on the left and are leptokurtic for the large and medium series. Finally, the Jarque-Bera statistic rejects in all cases the null hypothesis that the returns are normally distributed.

\section{EMPIRICAL RESULTS}

This section is divided into two sub-sections. The first section presents the estimates in-sample based on the proposed model. The second section focuses on the out-of-sample application of the size effect that was identified.

\section{In-sample results}

The first step in the VAR-BEKK model is to identify the best specification for the return series. For Ewing and Malik (2005), this is particularly important because an error in the equation specification can lead to incorrect variance equation estimation. Then the average conditional equation is set to VAR (2), determined according to the Akaike information criterion. Once the average structure is identified, we estimate the average and VAR-BEKK model variance specifications to avoid the problem caused by the regressor according to Ewing et al. (2002).

Table 3 shows, in Panel A, the estimated VAR model coefficients, in Panel $B$, the results of the BEKK asymmetric coefficients model, and in Panel $C$, the restriction test on the effects of variance.

As we can see in Table 3, Panel A, there are significant dynamic relationships in the return series of these three portfolios. The return of the Large series is heavily influenced by the fluctuation of its prices and of the Medium series, the return of the Medium series is highly influenced by the price fluctuations of the Large series, and the Small series is strongly influenced by the price fluctuations of the Medium series. In Panel B, we present the results of the BEKK asymmetric coefficients model, where low levels of critical significance obtained for most of the estimated parameters (in brackets) show that the model is well suited. Finally, in Panel $C$, we observe that the nullity of the effects of cross-variance $\left(a_{i j}=b_{i j} \forall i \neq j\right)$ is clearly rejected, as well as the nullity $a_{i j}=0$ e $b_{i j}=0$. We have also observed that the restrictions on the effects of cross-variance and covariance are clearly rejected. As a result, cross-links over all conditional moments and their shocks (symmetrical and on-symmetrical) cannot be ignored. Furthermore, the importance of considering the asymmetries is completely supported by the statistical probability ratio, which is calculated as $\mathrm{LR}=2\left[\mathrm{~L}\left(\Theta_{1}\right)-\mathrm{L}\left(\Theta_{0}\right)\right]$ where $\mathrm{L}\left(\Theta_{1}\right)$ and $\mathrm{L}\left(\Theta_{0}\right)$ is the value of the maximum log probability obtained by the multi-varied model with and without symmetry, respectively. This assumes a statistical distribution $\chi^{2}$. 
Table 3. VAR-BEKK model results

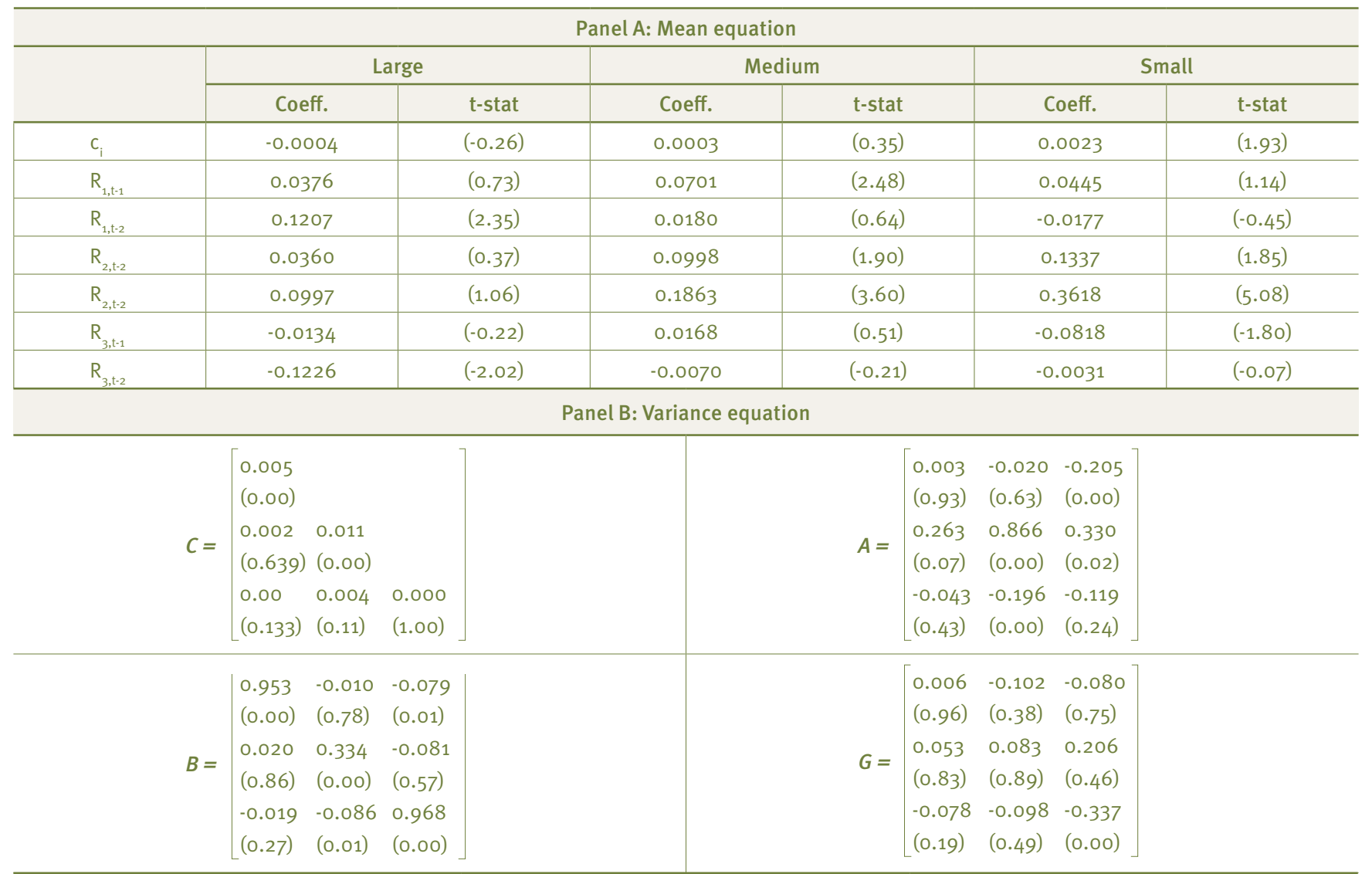

\begin{tabular}{|c|c|c|c|c|c|c|}
\hline \multicolumn{7}{|c|}{ Panel C: Restriction test on the effects of variance } \\
\hline & & \multicolumn{3}{|c|}{ Chi-squared } & \multicolumn{2}{|c|}{ (p-value) } \\
\hline $\mathrm{H}_{0}: \mathrm{a}_{\mathrm{ij}}=\mathrm{b}_{\mathrm{ij}} \forall \mathrm{i} \neq \mathrm{j}$ & & \multicolumn{3}{|c|}{155.738} & \multicolumn{2}{|c|}{$(0.00)$} \\
\hline $\mathrm{H}_{0}: \mathrm{b}_{\mathrm{ij}}=0$ & & \multicolumn{3}{|c|}{29.011} & \multicolumn{2}{|c|}{$(0.00)$} \\
\hline \multicolumn{7}{|c|}{ Panel D: Residual diagnostics } \\
\hline & \multicolumn{2}{|c|}{ Large } & \multicolumn{2}{|c|}{ Medium } & \multicolumn{2}{|c|}{ Small } \\
\hline & Coeff. & $p$-value & Coeff. & $p$-value & Coeff. & $p$-value \\
\hline \multirow[t]{3}{*}{ Sign } & -0.298 & $(0.144)$ & -0.048 & $(0.808)$ & 0.198 & $(0.338)$ \\
\hline & \multicolumn{2}{|c|}{ Large-medium } & \multicolumn{2}{|c|}{ Large-small } & \multicolumn{2}{|c|}{ Medium-small } \\
\hline & Lead & Lag & Lead & Lag & Lead & Lag \\
\hline Cross (20) & -0.0391 & -0.0177 & -0.0041 & -0.0012 & -0.0311 & -0.0450 \\
\hline
\end{tabular}


Following Engle and Ng (1993), Ling and Li (1997), Engle (2002) and Tse (2002), among others, tests for own autocorrelation, cross autocorrelation and asymmetry are conducted for the standardized residuals. Results are reported in Panel D of Table 3. First, the Ljung-Box statistics show that there is no autocorrelation in the residuals. Second, the null of no residual asymmetry is not rejected in the test for sign bias and, finally, cross-correlations are near zero for any and all time lag separations revealing the randomness of the residuals.

Finally, Table 4 presents the conditional variance results for each of the size portfolios. In the analysis presented in Table 4 , we observe critical data for our study. The medium portfolios are influenced by their own shocks and influenced (in the opposite direction) by the shocks of small portfolios, and we can also observe that they are influenced by the variance of small portfolios. Regarding the small portfolios, we can observe that they are influenced by their variance and indirectly by the variance of the large portfolios. In the case of large portfolios, they are influenced by its variance.

\section{Out-of-sample results}

After having observed the anomaly of size effect in the in-sample period, we implemented optimal strategies to obtain different yields and risks than those we would obtain if we simply adopted a naive strategy. Specifically, our analysis sought to reduce risk while achieving positive profitability. It should be also noted that we established relationships between asset classes as follows: Large / Medium, Large / Small, Medium / Small, and Large / Medium / Small.

Table 4. Conditional variance equations

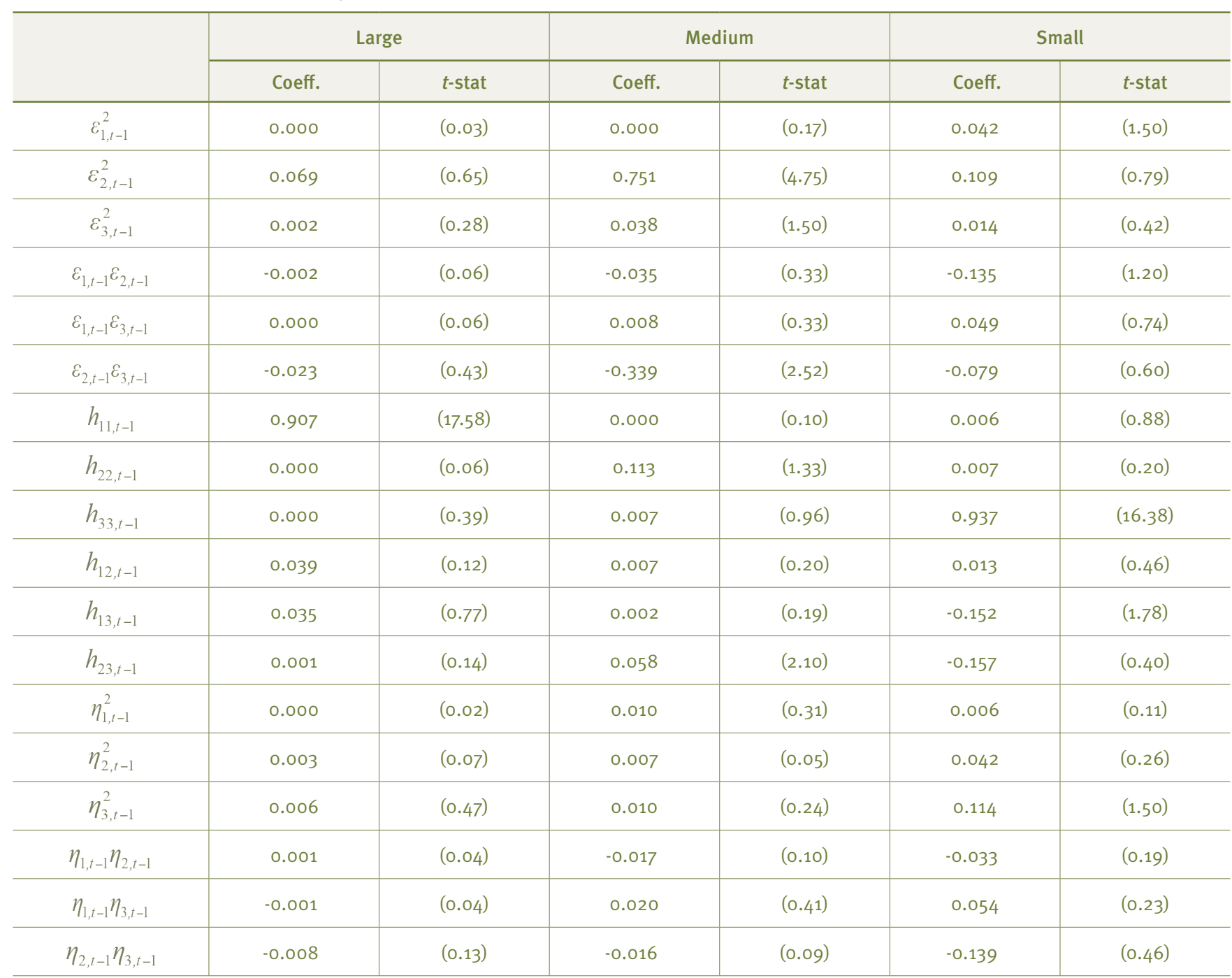


Table 5 shows the average weights of the portfolios in average values, based on the modeling of the out-of-sample period. As we can see in Panel A, the weight of the portfolios without short positions is more relevant than that of medium and small businesses in comparison with large businesses, and when we compare the medium and small, there are almost no differences. On the other hand, in Panel B, we present the average composition of optimal portfolios with short positions. We observe once again that in these portfolios, the medium and small assets are the most relevant.

When we analyze the results obtained in the relationship between the Large, Medium, and Small portfolios, we draw different conclusions for each. Our analysis sought to reduce risk while obtaining positive return through a mean-variance optimal strategy.

Table 5 . Weights of the optimal portfolios

\begin{tabular}{|c|c|c|c|}
\hline \multicolumn{4}{|c|}{ Panel A - without short positions } \\
\hline & Large & Medium & Small \\
\hline Large/Medium & 0.1146 & 0.6575 & -- \\
\hline Large/Small & 0.2861 & -- & 0.5185 \\
\hline Medium/Small & -- & 0.4271 & 0.4350 \\
\hline Large/Medium/Small & 0.0777 & 0.4346 & 0.2980 \\
\hline \multicolumn{4}{|c|}{ Panel B - with short positions } \\
\hline & Large & Medium & Small \\
\hline Large/Medium & -0.6382 & 1.6382 & -- \\
\hline Large/Small & 0.8020 & -- & 0.1980 \\
\hline Medium/Small & -- & 3.1950 & -2.1950 \\
\hline Large/Medium/Small & 0.2611 & 0.2952 & 0.4437 \\
\hline
\end{tabular}

Table 6 and Table 7 show the results obtained during the out-of-sample period for both naïve and optimal strategies proposed in this study in terms of profitability, risk, and Sharpe ratio. Specifically, in Table 6, we present the results when short positions are not allowed. We can observe that, in all cases, the adoption of an optimal strategy is significantly higher than the adoption of a naive strategy.
Table 6. Results of optimal portfolios without short positions

\begin{tabular}{|c|c|c|c|}
\hline \multicolumn{4}{|c|}{ Panel A: Profitability } \\
\hline & $\begin{array}{l}\text { Naïve } \\
\text { strategy }\end{array}$ & $\begin{array}{l}\text { Optimal } \\
\text { strategy }\end{array}$ & $\begin{array}{c}\text { Differences } \\
\text { optimal - } \\
\text { naive }\end{array}$ \\
\hline Large/Medium & 0.0385 & 0.1050 & 0.0665 \\
\hline Large/Small & 0.0785 & 0.1122 & 0.0337 \\
\hline Medium/Small & 0.0732 & 0.0995 & 0.0264 \\
\hline $\begin{array}{l}\text { Large/Medium/ } \\
\text { Small }\end{array}$ & 0.0634 & 0.1208 & 0.0574 \\
\hline \multicolumn{4}{|c|}{ Panel B: Risk } \\
\hline & $\begin{array}{l}\text { Naïve } \\
\text { strategy }\end{array}$ & $\begin{array}{l}\text { Optimal } \\
\text { strategy }\end{array}$ & $\begin{array}{c}\text { Differences } \\
\text { optimal - } \\
\text { naive }\end{array}$ \\
\hline Large/Medium & 0.1670 & 0.1139 & -0.0531 \\
\hline Large/Small & 0.1549 & 0.1163 & -0.0386 \\
\hline Medium/Small & 0.1402 & 0.1229 & -0.0172 \\
\hline $\begin{array}{l}\text { Large/Medium/ } \\
\text { Small }\end{array}$ & 0.1490 & 0.1108 & -0.0381 \\
\hline \multicolumn{4}{|c|}{ Panel C: Sharpe ratio } \\
\hline & $\begin{array}{l}\text { Naïve } \\
\text { strategy }\end{array}$ & $\begin{array}{l}\text { Optimal } \\
\text { strategy }\end{array}$ & $\begin{array}{c}\text { Differences } \\
\text { optimal - } \\
\text { naive }\end{array}$ \\
\hline Large/Medium & 0.2303 & 0.9220 & 0.6917 \\
\hline Large/Small & 0.5071 & 0.9649 & 0.4578 \\
\hline Medium/Small & 0.5219 & 0.8096 & 0.2877 \\
\hline $\begin{array}{l}\text { Large/Medium/ } \\
\text { Small }\end{array}$ & 0.4255 & 1.0898 & 0.6644 \\
\hline
\end{tabular}

Table 7 shows the results in which short positions are allowed, where we can observe that the adoption of an optimal strategy is better than the adoption of a naive strategy, except in one case, when we analyze the relationship between medium and small businesses. We can thus conclude that through the adoption of an optimal strategy, in which medium and small businesses have a higher weight, we can obtain extraordinary gains in the out-of-sample period. 
Table 7. Results of optimal portfolios with short positions

\begin{tabular}{|c|c|c|c|}
\hline \multicolumn{4}{|c|}{ Panel A: Profitability } \\
\hline & $\begin{array}{c}\text { Naive } \\
\text { strategy }\end{array}$ & $\begin{array}{l}\text { Optimal } \\
\text { strategy }\end{array}$ & $\begin{array}{c}\text { Differences } \\
\text { optimal - } \\
\text { naive }\end{array}$ \\
\hline Large/Medium & 0.0385 & 0.2680 & 0.2296 \\
\hline Large/Small & 0.0785 & 0.3217 & 0.2432 \\
\hline Medium/Small & 0.0732 & 1.3895 & 1.3164 \\
\hline $\begin{array}{l}\text { Large/Medium/ } \\
\text { Small }\end{array}$ & 0.0634 & 0.1823 & 0.1189 \\
\hline \multicolumn{4}{|c|}{ Panel B: Risk } \\
\hline & $\begin{array}{c}\text { Naive } \\
\text { strategy }\end{array}$ & $\begin{array}{l}\text { Optimal } \\
\text { strategy }\end{array}$ & $\begin{array}{c}\text { Differences } \\
\text { optimal - } \\
\text { naive }\end{array}$ \\
\hline Large/Medium & 0.1670 & 1.0766 & 0.9096 \\
\hline Large/Small & 0.1549 & 0.4219 & 0.2670 \\
\hline Medium/Small & 0.1402 & 3.5404 & 3.4002 \\
\hline $\begin{array}{l}\text { Large/Medium/ } \\
\text { Small }\end{array}$ & 0.1490 & 0.2015 & 0.0525 \\
\hline \multicolumn{4}{|c|}{ Panel C: Sharpe ratio } \\
\hline & $\begin{array}{c}\text { Naive } \\
\text { strategy }\end{array}$ & $\begin{array}{l}\text { Optimal } \\
\text { strategy }\end{array}$ & $\begin{array}{c}\text { Differences } \\
\text { optimal - } \\
\text { naive }\end{array}$ \\
\hline Large/Medium & 0.2303 & 0.2489 & 0.0187 \\
\hline Large/Small & 0.5071 & 0.7625 & 0.2554 \\
\hline Medium/Small & 0.5219 & 0.3925 & -0.1294 \\
\hline $\begin{array}{l}\text { Large/Medium/ } \\
\text { Small }\end{array}$ & 0.4255 & 0.9050 & 0.4795 \\
\hline
\end{tabular}

\section{CONCLUSIONS}

This study analyzes the transmission of information and the building of minimum-risk portfolios between large, medium, and small businesses in the Brazilian capital market (BOVESPA) using a multivariate GARCH methodology.

The result of the initial analysis performed on a multivariate GARCH model shows that there is a high degree of information transmission between these businesses on the BOVESPA. It is even more important in the case of medium-sized businesses because both their conditional volatility and shocks significantly influence, directly and indirectly, large and small companies.
These results are important for understanding the Brazilian stock market's behavior and for asset valuation, portfolio management, and investment strategies in following a minimum risk approach.

In addition to obtaining statistical results, we have also tried to obtain economic results, so this study could produce information of economic significance useful to users when making investment decisions. The out-of-sample results show that through the adoption of an optimal strategy, we can obtain extraordinary results in economic terms in comparison with the adoption of a naive strategy for small and medium businesses.

Any future studies should be directed towards reanalyzing the traditional anomalies observed in capital markets, taking into account whether they allow extraordinary economic gains in an out-of-sample period. In the case of Brazil's stock exchange, it would be of value to analyze other empirical anomalies such as those relating to the book-to-market effect, making a distinction between growth assets and value assets using this same methodology.

\section{ACKNOWLEDGEMENTS}

This paper has been financially supported by the Junta de Extremadura (JUNTAEX) under the V Action Plan for Research and Development 2014/17 through the GIMAF research group (reference GR15027).

\section{REFERENCES}

Ahmad, W., Sehgal, S., \& Bhanumurthy, N. R. (2013). Eurozone crisis and BRIICKS stock markets: Contagion or market interdependence. Economic Modelling, 33, 209-225. doi: 10.1016/j. econmod.2013.04.009

Amel-Zadeh, A. (2011). The return of the size anomaly: Evidence from the German stock market. European Financial Management, 17, 45182. doi: 10.1111/j.1468-036X.2010.00581.X

Antunes, G. A., Lamounier, W. M., \& Bressan, A. A. (2006). Análise do efeito tamanho nos retornos das ações de empresas listadas na BOVESPA. Revista Contabilidade \& Finanças, 17(40), 87-101. doi: 10.1590/S1519-70772006000100007

Baba, Y., Engle, R., Kraft, D., \& Kroner, K. (1991). Multivariate simultaneous generalized ARCH. Department of Economics, MS, University of California, San Diego.

Banz, R. (1981). The relationship between return and market value of common stocks. Journal of Financial Economics, 9, 3-18. doi: 10.1016/0304-405X(81)90018-0

Basu, S. (1977). Investment performance of common stocks in relation to their price-earnings ratios: A test of the efficient market hypothesis. The Journal of Finance, 32, 663-682. doi: 10.2307/2326304 
Bergés, A., Mcconnell, J., \& Schlarbaum, G. (1984). The turn-of the-year in Canada. Journal of Finance, 1, 185-192. doi: 10.2307/2327675

Berk, J. (1997): “Does size really matter? Financial Analyst Journal, 53(5), 12-18. doi: 10.2469/faj.v53.n5.2112

Blume, M., \& Stambaugh, R. (1983). Biases in computed returns: An application to the size effect. Journal of Financial Economics, 12(3), 387-404. doi: 10.1016/0304-405X(83)90056-9

Bowers J. E, \& Dimson, E. (1988). Introduction. In E. Dunson (Ed.), Stock Market Anomalies. Cambridge (New York): Cambridge University Press.

Brown, P., Keim, D., Kleidon, A., \& Marsh, T. (1983). Stock return seasonalities and the tax-loss selling hypothesis: Analysis of the arguments and Australian evidence. Journal of Financial Economics, 12, 105-127. doi: 10.1016/0304-405X(83)90030-2

Cakici, N., Fabozzi, F., \& Tan, S. (2013). Size, value, and momentum in emerging market stock returns. Emerging Markets Review, 16, 46-65. doi: $10.1111 /$ ajfs.12086

Carhart, M. M. (1997). On persistence in mutual fund performance. Journal of Finance, 52(1), 57-82. doi: 10.1111/j.1540-6261.1997. tbo3808.x

Chan, K. C., Nai-Fu, C., \& Hsieh, D. (1985) An explanatory investigation of the firm size effect. Journal of Financial Economics, 14, 451-471. doi: $10.1016 / 0304-405 \times(85) 90008-X$

DeMiguel, V., Garlappi, L., Nogales, F., \& Raman, U. (2009). A generalized approach to portfolio optimization: Improving performance by constraining portfolio norms. Management Science, 55, 798-812.

Eid, W., \& Romaro, P. (2002). Efeito tamanho na Bovespa. Anais do XXIII CLADEA, Porto Alegre, 1, 1-12.

Engle, R. F. (2002). Dynamic conditional correlations: A simple class of multivariate GARCH models. Journal of Business and Economic Statistics, 20, 339-350. doi: 10.1198/073500102288618487

Engle, R. F., \& Ng, V. K. (1993). Measuring and testing the impact of news on volatility. Journal of Finance, 48, 1749-1778. doi: $10.2307 / 2329066$

Ewing, B., \& Malik, F. (2005). Re-examining the asymmetric predictability of conditional variances: The role of sudden changes in variance. Journal of Banking and Finance, 29, 2655-2673. doi: 10.1016/j. jbankfin.2004.10.002

Ewing, B. T., Malik, F., \& Ozfidan, O. (2002). Volatility transmission in the oil and natural gas markets. Energy Economics, 24, 525-538. doi: 10.1016/S0140-9883(02)00060-9

Fama, E. (1991). Efficient capital markets. Journal of Finance, 5, 15751617. doi: $10.2307 / 2328565$

Fama, E., \& French, K. (1995). Size and book-to-market factors in earnings and returns. Journal of Finance, 50(1), 131-155. doi: 10.2307/2329241

Fama, E., \& French, K. (2008). Dissecting anomalies. Journal of Finance, 63, 1653-1678. doi: 10.1111/j.1540-6261.2008.01371.x

Fama, E., \& French, K. (2012) Size, value, and momentum in international stock returns. Journal of Financial Economics, 105, 457-682. doi: 10.1016/j.jfineco.2012.05.011

Flister F., Bressan, A., \& Amaral, H. (2011). CAPM condicional no mercado brasileiro: Um estudo dos efeitos momento, tamanho e book-to-market entre 1995 e 2008. Revista Brasileira de Finanças, 9(1), 105-129.
Fouse, W. (1989). The 'small stocks' hoax. Financial Analysis Journal, 45, 12-15.

Glosten, L., Jaganathan, R., \& Runkle, D. (1993). On the relation between the expected value and the volatility of the nominal excess return on stocks. Journal of Finance, 48(5), 1779-1801. doi: 10.1111/j.15406261.1993.tbo5128.x

Grinblatt, M., \& Moskowitz, T. (2002). What do we really know about the cross-sectional relation between past and expected returns? Working Paper 8744, National Bureau of Economic Research, 1-37.

Hassan, S., \& Malik, F. (2007). Multivariate GARCH modeling of sector volatility transmission. The Quarterly Review of Economics and Finance, 47, 470-480. doi: 10.1016/j.qref.2006.05.006

Ibbotson, R., \& Sinquefield, R. (1976). Stocks, bonds, bills and inflation: Simulations of the future (1976-2000). Journal of Business, 49(3), 313-338.

Israel, R., \& Moskowitz, T. (2013). The role of shorting, firm size, and time on market anomalies. Journal of Financial Economics, 108, 275301. doi: 10.1016/j.jfineco.2012.11.005

Karmakar, M. (2010). Information transmission between small and large stocks in the national stock exchange in India: An empirical study. The Quarterly Review of Economics and Finance, 50, 110-120. doi: 10.1016/j.qref.2009.09.007

Keim, D. (1983). Size-related anomalies and stock return seasonality: Further empirical evidence. Journal of Financial Economics, 12, 13-32. doi: 10.1016/0304-405X(83)90025-9

Keim, D., \& Stambaugh, R. (1984). A further investigation of the weekend effect in stock returns. Journal of Finance, 3, 819-840. doi: 10.1111/j.1540-6261.1984.tbo3675.x

Kroner, K., \& Ng, V. (1998). Modeling asymmetric comovements of asset returns. Review of Financial Studies, 11, 817-844. doi: 10.1093/ $\mathrm{rfs} / 11.4 .817$

Ledoit, O., \& Wolf, M. (2008). Robust performance hypothesis testing with the Sharpe ratio. Journal of Empirical Finance, 15, 850-859. doi: 10.1016/j.jempfin.2008.03.002

Lima, F., Costa, M., \& Bruni, A. (2005). Anomalias em mercados de capitais: Uma análise do efeito tamanho na bolsa de valores de São Paulo com o uso do CAPM e do modelo de mercado. Revista Gestão e Planejamento, 11, 23-28.

Ling, S., \& Li, W. K. (1997). Diagnostic checking of nonlinear multivariate time series with multivariate ARCH errors. Journal of Time Series Analysis, 18, 447-464. doi: 10.1111/1467-9892.00061

Lucena, P., \& Figueiredo, A. (2004). Pressupostos de eficiência de mercado: Um estudo empirico na Bovespa. Revista Eletrônica de Gestão Organizacional, 2(3). Retrieved from https://periodicos.ufpe. $\mathrm{br} /$ revistas/gestaoorg/index).

Machado, M., \& Machado, M. (2014). Liquidez e precificação de ativos: Evidências do mercado brasileiro. Brasilian Business Review, 11, 73-95.

Markowitz, H. (1952). Portfolio selection. Journal of Finance, 7, 77-91. doi: 10.1111/j.1540-6261.1952.tb01525.x

Matsumoto A., \& Lima, F. (2004). Efeito tamanho: Evidências no mercado acionário brasileiro. In IV Congresso USP de Controladoria e Contabilidade, 2004, São Paulo (SP). Anais do IV Congresso USP de Controladoria e Contabilidade. 
Miralles-Marcelo, J. L., Miralles-Quiros, J. L., \& Miralles-Quiros, M. M. (2011). Transmisión de información y carteras óptimas en el mercado bursátil español. Cuadernos de Economía y Dirección de la Empresa, 14, 247-257. doi: 10.1016/j.cede.2010.12.001

Miralles-Quirós, M. M., \& Miralles-Quirós, J. L. (2017). Improving diversification opportunities for socially responsible investors. Journal of Business Ethics, 140 (2), 339-351. doi: 10.1007/S10551-015-2691-4

Nakamura, T., \& Terada, N. (1984). The size effect and seasonality in Japanese stock returns. Nomura Research Institute. Retrieved from https://www. jstor.org/stable/2648877?seq=1\#page_scan_tab_contents

Reinganum, M. (1981). The arbitrage pricing theory: Some empirical results. The Journal of Finance, 36, 313-321. doi: 10.1111/j.15406261.1981.tboo444.x

Reinganum, M., \& Shapiro, A. (1987). Taxes and stock return seasonality: Evidence from the London Stock Exchange. Journal of Business, 2, 281-295.

Roll, R. (1981). A possible explanation of the small firm effect. Journal of Finance, 36, 879-888. doi: $10.2307 / 2327553$

Roll, R. (1983). Vas ist das? The turn-of-the-year effect and the return premia of small firms. Journal of Portfolio Management, 9, 18-28. doi: 10.3905/jpm.1983.18
Saturnino, O., Saturnino, V., Lucena, P., Carmona, C., \& Araújo, L. F. (2012). Investimento em valor contrário no Brasil: Overreaction ou efeito tamanho? Revista de Finanças Aplicadas, 1, 1-20.

Silvennoinen, A., \& Teräsvirta, T. (2009). Multivariate GARCH models. In T. G. Andersen, R. A. Davis, J.-P. Kreiss, \& T. V. Mikosch (Eds.), Handbook of Financial Time Series, Springer, pp 201-232.

Tse, Y. K. (2002). Residual-based diagnostics for conditional heteroscedasticity models. Econometric Journal, 5, 358-373. doi: 10.1111/1368-423X.t01-1-00088

Van Dijk, M. (2011). Is size dead? A review of the size effect in equity returns. Journal of Banking and Finance, 35, 3263-3274. doi: 10.1016/j.jbankfin.2011.05.009

Zakamulin, V. (2013). Forecasting the size premium over different time horizons. Journal of Banking and Finance, 37, 1061-1072. doi: 10.1016/j.jbankfin.2012.11.006

Zhang, B., \& Li, X. (2014). Has there been any change in the comovement between the Chinese and US stock markets? International Review of Economics and Finance, 29, 525-536. doi: 10.1016/j.iref.2013.08.001 